\title{
Determination of the time of death of dogs using atropine and pilocarpine in the early post-mortem period - an assessment of the usefulness of the method
}

\author{
KINGA PANASIUK-FLAK, MAŁGORZATA GRELA, PIOTR LISTOS
}

\begin{abstract}
Sub-Department of Pathomorphology and Forensic Medicine, Department and Clinic of Animal Internal Diseases, Faculty of Veterinary Medicine, University of Life Sciences in Lublin, Głęboka 30, 20-033 Lublin
\end{abstract}

\section{Panasiuk-Flak K., Grela M., Listos P.}

\section{Determination of the time of death of dogs using atropine and pilocarpine in the early post-mortem period - an assessment of the usefulness of the method}

\section{Summary}

To determine the time of death in the early post-mortem period, i.e. up to a few hours or a few days, methods involving measurement of body temperature and observations of supravital reactions are used. One of the most promising methods is measurement of the reactivity of the pupil under the influence of substances such as those used in this study, atropine and pilocarpine. The research material was two groups of dogs, one with body weight over $40 \mathrm{~kg}$ and another under $10 \mathrm{~kg}$, whose time of death was known. At 30, 60, 90 , 120 and 180 minutes post-mortem, atropine or pilocarpine drops were placed in the conjunctival sac and the change in pupil diameter was measured. The study clearly showed that the method is useful in forensic estimation of the time of death of an animal. In order to verify the reliability of the method, there is a need for further study.

Keywords: veterinary forensics, time of death, atropine and pilocarpine

Determination of the time passed since the death of a human being in forensic medicine or of an animal in forensic veterinary medicine is extremely complicated and requires a specialist's knowledge and experience. When a case involves the death of an animal, the judicial body in need of an opinion calls on experts in the field of veterinary medicine. Expert veterinarians mainly examine live injured animals and perform necropsies to determine the cause of an animal's death and time of death. The latter is determined based on evaluation of supravital reactions, biochemical tests, tests of the degradation of genetic material, characteristic changes taking place in the body after death in a specific environment, or entomological analysis of the development of insects found on the body. These tests are extremely useful in ascertaining the circumstances of a case, sometimes despite the lack of sufficient information from witnesses, and thus can allow judicial bodies to uncover the truth.

In practice, the methods used to determine the time of death in the early post-mortem period, i.e. up to a few hours or a few days, involve measurement of the temperature of the body and observation of supravital reactions $(3,11,24)$. Forensic diagnosis of death is also based on the presence of characteristic post-mortem changes. These appear in varying order and develop at different rates, depending on a number of important factors, including injury, environmental conditions, covering of the body, hair thickness, the geometry of the body, etc. (21). Among characteristic post-mortem changes we distinguish conclusive early changes based on which death can be ascertained, such as livor mortis and rigor mortis; inconclusive early changes, such as algor mortis, pallor mortis, and drying out of the body, which develop and evolve within 12 hours after death; late changes associated with decomposition autolysis and putrefaction; and processes that preserve the body, such as saponification, skeletonization, and mummification.

Issues connected with analysis of late post-mortem changes have been discussed exhaustively in the English-language literature, in contrast with phenomena taking place in the body in the early post-mortem period, particularly supravital reactions, which remain a challenge for pathologists, forensic experts, and veterinary forensic experts.

The supravital period is a period that begins with clinical death. At this time entire organs exhibit signs of life, retaining the physiological capacity to react to mechanical, thermal, pharmacological and electrical 
stimuli. This is because during clinical death many cells, tissues and even organs exhibit vital functions, which is directly correlated with the need for oxygen and sensitivity to its deficiency. In most cases clinical death gradually changes into brain death. The final stage of death is biological death, which is the end of the supravital process and the final death of the entire organism (7). Responses induced during the supravital period, known as supravital reactions, weaken over time until they stop completely. Observation of supravital phenomena can be used to determine the time of death of an individual in the early post-mortem period. An example is examination of the mechanical and electrical excitability of muscles (27).

One of the most promising methods for accurately determining the time of death is the application of pharmacological agents (mainly alkaloids: pilocarpine, acetylcholine, atropine, ergometrine, and papaverine) to the anterior chamber of the eye and observation of the resulting dilation or constriction of the pupil up to 20 h post-mortem $(7,26)$.

In the empirical part of this study, an experiment was carried out to determine the usefulness of atropine and pilocarpine solutions for approximate estimation of the time of death of an animal.

\section{Material and methods}

The research material consisted of domestic dogs from amateur breeding, which due to age-related health problems with an unfavourable prognosis were euthanized by intravenous injection with Morbital in the amount of 0.3-0.6 $\mathrm{ml} / \mathrm{kg}$ BW (pentobarbital sodium 39.99-79.98 mg/kg BW and pentobarbital $8.01-16.02 \mathrm{ml} / \mathrm{kg} \mathrm{BW}$ ), after which they were turned over by their legal caretakers for the purposes of scientific research.

The experiment was carried out in the necropsy room of the Sub-Department of Pathomorphology and Forensic Medicine, University of Life Sciences in Lublin, where the environmental conditions were kept constant: $19^{\circ} \mathrm{C}$ air temperature and about $55 \%$ humidity.

The animals were divided into two groups according to their body weight. The first group comprised 5 dogs whose body weight was more than $40 \mathrm{~kg}(41,46.3,42.1$, 48 , and $40.5 \mathrm{~kg}$ ), while the other group consisted of $5 \mathrm{dogs}$ whose body weight did not exceed $10 \mathrm{~kg}$ $(6,3.2,8,9.8$, and $10 \mathrm{~kg})$.

Eye drop solutions were introduced into the conjunctival sacs of each dog at 30, 60, 90, 120 and 180 min following euthanasia as follows: atropinum sulfuricum WFZ $1 \%, 10 \mathrm{mg} / \mathrm{ml}$ (Polfa S.A. Pharmaceutical Works) -5 drops in the right eye, and pilocarpinum WZF $2 \%, 20 \mathrm{mg} / \mathrm{ml}$ (Polfa S.A. Pharmaceutical Works) -5 drops in the left eye. After 10 min the diameter of the right and left pupils was measured with a calliper.

\section{Results and discussion}

Following application of atropinum sulfuricum WZF $1 \%$ into the right eye of the dogs, dilation of the pupils or a lack of reactivity was observed, while administration of pilocarpinum WZF $2 \%$ into the left eye was followed by constriction of the pupils. The data are presented in the table below (Tab. 1).

Determination of the time passed since the death of a human being or animal is a challenge for doctors of both human and veterinary medicine. As yet there has been no method developed that gives a highly precise estimation of the time of death. The large margin of error is due to the varying intensity of post-mortem changes, depending on the species, breed, body geometry, hair coat, amount of fat tissue, cause of death, and ambient conditions (temperature and humidity). Other factors include age, physical activity, and the individual's health condition before death $(3,21,22)$. Attempts to determine the time of death are often made in cases where important information from the site where the body was found is lacking, due to a delayed or cursory examination of the body or a failure to measure its temperature. Knowledge of the time since death is essential in the case of violent deaths, because it indicates the probable time when a crime was committed $(8,16,25)$. The most common means of estimating the time of death is analysis of post-mortem cooling of the body. In determining the post-mortem interval using temperature measurements, it is important to take into account the effect of biological processes taking place in the individual, such as fever or hypothermia preceding death, as well as the physical and anatomical conditions of the individual (6). In addition, in 1962 Marshall and Hoare observed that various activities connected with the handling the body (e.g. carrying, overturning, covering or unclothing it) significantly interfere with heat flow, which often contributes to er-

Tab. 1. Effect of atropine and pilocarpine drops applied to the conjunctival sac on pupil diameter at various intervals after the death of dogs in groups 1 (body weight above $40 \mathrm{~kg}$ ) and 2 (body weight below $10 \mathrm{~kg}$ )

\begin{tabular}{|c|c|c|c|c|c|}
\hline Group & $\begin{array}{c}\text { Carcass } \\
\text { no. }\end{array}$ & $\begin{array}{c}\text { Post-mortem } \\
\text { interval (min) }\end{array}$ & $\begin{array}{c}\text { Pupil diameter } \\
\text { before administration } \\
\text { of drops }(\mathrm{mm})\end{array}$ & $\begin{array}{c}\text { Pupil diameter } \\
\text { after administration } \\
\text { of atropine }(\mathrm{mm})\end{array}$ & $\begin{array}{c}\text { Pupil diameter } \\
\text { after administration } \\
\text { of pilocarpine (mm) }\end{array}$ \\
\hline \multirow{3}{*}{1} & 1 & 30 & 4 & 8 & 1 \\
& 2 & 60 & 4 & 7 & 2 \\
& 3 & 90 & 5 & 7 & 3 \\
& 4 & 120 & 4 & 5 & 3 \\
\hline & 5 & 180 & 4 & 4 & 4 \\
& 1 & 30 & 3 & 7 & 2 \\
& 2 & 60 & 4 & 6 & 3 \\
\hline
\end{tabular}


rors in estimating the time of death (20). Estimation of the post-mortem interval also requires a model of the curve of the decrease in temperature over time (21). In addition, the need to take into account the plateau stage in the cooling of the body and the atmospheric conditions it has been in, including the amount of sunlight, further complicates determination of the post-mortem interval based on temperature measurement, and thus can generate errors.

Researchers have shown interest in estimation of the post-mortem interval based on changes in the eyeball. Measurements of the temperature of the vitreous body of the eye (9), observations of retinal blood vessel segmentation, and analysis of changes in the colour of the cornea and the degree of corneal clouding depending on the time passed since death are techniques that have been used successfully for years. Studies by Kaliszan et al. and Listos et al., however, indicate that for precise estimation of the time of death in both humans and animals, the temperature of the soft tissues of the eye must be measured up to about $12 \mathrm{~h}$ post-mortem $(10,15)$.

One of the most promising methods of determining the time of death is to assess the pharmacological reactivity of the pupil. This method was first described in 1885 by J. N. Marshall (19). In 1978, Klein and Klein conducted an experiment on the pharmacological excitability of the iris in human carcasses. They concluded that this method is of practical value in estimating time of death up to $30 \mathrm{~h}$ when Mydriaticum Roche is used, and up to $46 \mathrm{~h}$ in the case of acetylcholine (12).

Although post-mortem measurement of the diameter of the pupils has been the subject of a number of studies, the methodology has not been standardized. Marshall used a scale (19), while Willer H. described the use of an optical method to measure the diameter of the pupil to within a tenth of a millimetre (28). This method was also adopted by other researchers (4), who sometimes modified it using a keratometer, e.g. Klein and Klein in 1978 (11), while Orrico M. et al. used a measuring tape (23). A study conducted in 2017 by Fleischer and Sehner, showing great potential, involved the use of a digital camera with ImageJ software to measure the pupil (5). A similar method was used by Koehler and Sehner to study the effect of acetylcholine and tropicamide in the bodies of 137 people whose time of death was known (14).

The present study, similarly to an experiment by Bardzik using 50 human bodies, involved the use of atropine and pilocarpine solutions $(1,2)$. The results reported by Bardzik are very similar to those obtained in our experiment, in which dogs were the research model. The author found that the dilating effect of atropine, as well as the adrenaline used in his experiment, is fairly slow, usually taking place about 5-10 min after the drops are applied, and that the magnitude of the reaction ranged from barely perceptible to a maximum 3-4 $\mathrm{mm}$ increase in pupil diameter.
In our experiment, changes in pupil diameter were noted at 30, 60, 90, 120 and 180 min post-mortem when atropine drops were applied to the anterior chamber of the eye. In the first group of dogs (over $40 \mathrm{~kg} \mathrm{BW}$ ), at $30 \mathrm{~min}$ post-mortem the drops caused the pupil to dilate to $8 \mathrm{~mm}$, which was $4 \mathrm{~mm}$ wider than the initial diameter. When the drops were administered at $60 \mathrm{~min}$ post-mortem, the diameter of the pupil was $7 \mathrm{~mm}$, and the result was the same at 90 minutes. Later (120 min post-mortem) the diameter was $5 \mathrm{~mm}$, a difference of $1 \mathrm{~mm}$ relative to the pupil diameter immediately after death. No change was noted in the pupil diameter after $180 \mathrm{~min}$. The results obtained in the second group of dogs (body weight under $10 \mathrm{~kg}$ ) are analogous to the results for group 1 . The increase in the pupil diameter was $4 \mathrm{~mm}$ at 30 min post-mortem, and $1 \mathrm{~mm}$ at 120 and $180 \mathrm{~min}$. The waiting time for the change was similar to that reported by Bardzik, ranging from 5 to $10 \mathrm{~min}$ utes. Bardzik's observation that the reaction time was much shorter in the case of pilocarpine (12-20 s) was also confirmed. In the first group, pilocarpine applied at $30 \mathrm{~min}$ after death resulted in constriction of the pupil from $4 \mathrm{~mm}$ to $1 \mathrm{~mm}$ (change of $3 \mathrm{~mm}$ ): at 60 and $90 \mathrm{~min}$ the change was $2 \mathrm{~mm}$; at $120 \mathrm{~min} 1 \mathrm{~mm}$; and at $180 \mathrm{~min}$ post-mortem the pupil showed no reactivity. In the second group of dogs, the change after $30 \mathrm{~min}$ was $2 \mathrm{~mm}$, and by $120 \mathrm{~min}$ post-mortem there was no reaction. Bardzik observed an average change of 1-2 mm, which is consistent with our results.

In the present study, in dogs with lower body weight (up to $10 \mathrm{~kg}$ ), the reaction of the pupils to pharmacological stimuli in the form of atropine and pilocarpine was similar to that noted in the group of large dogs. Differences became evident in the later stage of the experiment (120 and $180 \mathrm{~min}$ post-mortem) when the pupils of dogs weighing less than $10 \mathrm{~kg}$ stopped responding to stimuli more quickly. In both cases (pilocarpine and atropine), there was a tendency towards longer pharmacological reactivity of the pupils in dogs whose body weight exceeded $40 \mathrm{~kg}$. These results clearly suggest the need to take body weight into account in determining the post-mortem interval. It has not yet been established what differences may occur depending on species, breed, sex, age, or the physical condition of animals preceding death, which may also potentially affect the results.

An experiment using atropine and pilocarpine was also carried out in 2002-2003 by Orrico and Melotti, who analysed the reactivity of pupils in 309 human corpses and assessed the possibility of a reaction during a period up to $26 \mathrm{~h}$ post-mortem. Their most important conclusion was that analysis of the pharmacological reactivity of the pupil as a method of estimating time of death is not only a dubious method, but often leads to error (23).

Analysis of the literature leads to the conclusion that many of the publications describing the post-mortem excitability of the pupil contain conflicting and in- 
complete information on the experiments conducted. The main shortcomings are the small number of cases, varied means of application of substances (drops or injections) and of measuring pupil size, and the fact that the reliability of the results cannot be tested. Another problem in analysing the data is the conflicting results, as there are positive reactions - dilation of the pupils following the use of atropine and constriction following pilocarpine, negative reactions, i.e. no change in pupil diameter, and questionable reactions. The frequency of questionable or negative reactions reduces the reliability of the test. Therefore it seems necessary to standardize the methodology and to analyse larger numbers of cases.

To sum up, in both human and veterinary forensic medicine, determination of the time passed since death in the early post-mortem period is extremely important, and to be reliable, should be based on analyses combining temperature and non-temperature methods, of which the most valuable is evaluation of post-mortem excitability of the pupil, presented in this paper $(6,17$, 18). The combination of techniques makes it possible to obtain the most reliable estimate of the time passed since the death of a human being or animal.

\section{References}

1. Bardzik S.: Reakcje suprawitalne źrenic wywołane środkami farmakologicznymi o działaniu miotropowym. Arch. Med. Sąd. i Krym. 1968, 18, 267-275.

2. Bardzik S.: The efficiency of methods of estimating the time of death by pharmacological means. J. Forensic Med. 1966, 13, 141-143.

3. Brooks J. W. Postmortem changes in animal carcasses and estimation of the postmortem interval. Vet. Pathol. 2016, 53, 929-940.

4. Faller-Marquardt M., Pollak S.: Zum Einfluss der Umgebungstemperaturauf den Ablauf der spontanen postmortalen Pupillenmessungen (Unter-suchungen am Kaninchenauge). Beitr. Gerichtl. Med. 1992, 50, 325-332.

5. Fleischer L., Sehner S., Gehl A., Riemer M., Raupach T., Anders S.: Measurement of postmortem pupil size: A new method with excellent reliability and its application to pupil changes in the early postmortem period. J. Forensic Sci. 2017, 62, 791-795.

6. Henssge $C$., Madea B.: Estimation of the time since death in the early postmortem period. Forensic Sci Int. 2004, 144, 167-175.

7. Jakliński A., Kobiela J. S.: Medycyna sądowa. Państwowy Zakład Wydawnictw Lekarskich, Warszawa 1972.

8. Kaliszan M.: Próba określenia czasu zgonu na podstawie ograniczonych danych z miejsca ujawnienia zwłok. Arch. Med. Sąd. Krym. 2012, 62, 203-207.

9. Kaliszan M., Hauser R.: Określenie czasu zgonu na podstawie pomiaru temperatury oka wobec innych miejsc ciała. Arch. Med. Sąd. Krym. 2007, 57, 399-405

10. Kaliszan M., Hauser R., Buczyński J., Jankowski Z., Raczyńska K., KernbachWighton G.: The Potentia Use of the Eye Temperature Decrease in Determining the Time of Death in the Early Postmortem Period. Studies in Pigs. Am. J. Forensic Med. Pathol. 2010, 31, 162-164

11. Kaliszan M., Hauser R., Kernbach-Wighton G.: Estimation of the time of death based on the assessment of post mortem processes with emphasis on body cooling. Legal Medicine 2009, 11, 111-117.

12. Klein S., Klein A.: Die Todeszeitbestimmung am menschlichen Auge. Medical Academy of Dresden. Medical Dissertation. Dresden, Germany 1978.

13. Knight B. (ed.): The estimation of the time since death in the early postmortem period. Arnold, London 2002.

14. Koehler K., Sehner S., Riemer M., Gehl1 A., Raupach T., Anders S.: Postmortem chemical excitability of the iris should not be used for forensic death time diagnosis. Int. J. Leg. Med. 2018, 132, 1-5.

15. Listos P., Gryzińska M., Batkowska J.: Post-mortem decrease in temperature in the orbit of dogs for use in determining time of death. Slo. Vet. Res. 2016 52, 85-90.

16.Listos P., Gryzińska M., Batkowska J., Dylewska M., Czepiel-Mil K.: Application of research in the field of forensic entomology for determining the time of death in dogs. Med. Weter. 2018, 74, 33-38.
17. Madea B. (red.): Estimation of the time since death, $3^{\text {rd }}$ edn. CRC, Press, New York 2016

18. Madea B.: Methods for determining time of death. Forensic. Sci. Med. Pathol. 2016, 12, 451-485.

19. Marshall J. N.: On the changes in the pupil after death. Lancet 1885,126 , 286-288.

20. Marshall T. K., Hoare F.: Estimating the time since death - the rectal cooling after death and its mathematical representation. J. Forensic Sci. 1962, 7, 56-81.

21. Muggenthaler H., Sinicina I., Hubig M., Mall G.: Database of post-mortem rectal cooling cases under strictly controlled conditions: a useful tool in death time estimation. Int. J. Legal. Med. 2012, 126, 79-87.

22. Munro R., Munro H. M. C.: Some challenges in forensic veterinary pathology: a review. J. Comp. Pathol. 2013, 149, 57-73.

23. Orrico M., Melotti R., Mantovani A., Avesani B., de Marco R., de Leo D. Criminal investigations: pupil pharmacological reactivity as method for assessing time since death is fallacious. Am. J. Forensic Med. Pathol. 2008, 29, 304-308.

24. Pounder D. J.: Postmortem interval, [in:] Payne-James J. (ed.): Encyclopedia of Forensic and Legal Medicine, Elsevier, Oxford, UK 2005, 485-486.

25. Prabucki R., Wielki R.: Czas zgonu w kontekście nauk penalnych. Zeszyty naukowe ruchu studenckiego 2016, 1, 28-42.

26. Raszeja S.: Refleksje na temat tanatologii - klasycznego działu medycyny sądowej. Annales Academiae Medicae Gedanensis 2005, 35, 166-167.

27. Śliwka K.: Ocena pośmiertnej pobudliwości elektrycznej mięśnia szkieletowego szczurów i jej znaczenie dla określania czasu śmierci. Ann. Acad. Med. Gedan. 1984, 14, 9.

28. Willer H.: Ergebnisse von Pupillenmessungen an der Leiche. Dtsch. Z. Ges. Gerichtl. Med. 1926, 6, 22-32.

Corresponding author: Assoc. Prof. Piotr Listos, DVM, PhD Master of law, PhD, Department and Clinic of Animal Internal Diseases Sub-Department of Pathomorphology and Forensic Medicine Faculty of Veterinary Medicine University of Life Sciences in Lublin, Glęboka 30, 20-612 Lublin, Poland; e-mail: piotr.listos@up.lublin.pl 